\title{
The Feminist Politics of Choice: Lipstick as a Marketplace Icon
}

\author{
Lauren Gurrieri \\ RMIT University \\ Jenna M. Drenten \\ Loyola University Chicago, jdrenten@luc.edu
}

Follow this and additional works at: https://ecommons.luc.edu/business_facpubs

Part of the Business Commons

\section{Author Manuscript}

This is a pre-publication author manuscript of the final, published article.

\section{Recommended Citation}

Gurrieri, Lauren and Drenten, Jenna M.. The Feminist Politics of Choice: Lipstick as a Marketplace Icon. Consumption Markets \& Culture, , : , 2019. Retrieved from Loyola eCommons, School of Business: Faculty Publications and Other Works, http://dx.doi.org/10.1080/10253866.2019.1670649

This Article is brought to you for free and open access by the Faculty Publications and Other Works by Department at Loyola eCommons. It has been accepted for inclusion in School of Business: Faculty Publications and Other Works by an authorized administrator of Loyola eCommons. For more information, please contact ecommons@luc.edu.

\section{(c) $($ () $\ominus$}

This work is licensed under a Creative Commons Attribution-Noncommercial-No Derivative Works 3.0 License. (c) Taylor and Francis Online, 2019. 
Gurrieri, Lauren, and Jenna Drenten (2019), "The feminist politics of choice: Lipstick as a marketplace icon" Consumption Markets \& Culture, DOI: 10.1080/10253866.2019.1670649.

Note: This is a preprint version. The final published version of the paper may reflect notable format and content changes.

The feminist politics of choice: Lipstick as a marketplace icon

\author{
Lauren Gurrieri \\ Senior Lecturer in Marketing \\ School of Economics, Finance and Marketing \\ RMIT University \\ Building 80, Level 10 (Room 22) \\ 445 Swanston Street \\ Melbourne, VIC 3000 \\ Australia \\ + 61399255419 \\ lauren.gurrieri@rmit.edu.au \\ Jenna Drenten \\ Assistant Professor of Marketing \\ Quinlan School of Business \\ Loyola University Chicago \\ Schreiber Center 717 \\ 16 E. Pearson Street \\ Chicago, IL 60611 \\ (312) 915-6150 \\ jdrenten@luc.edu
}


The feminist politics of choice: Lipstick as a marketplace icon

\begin{abstract}
Lipstick has been a dominant beauty practice across cultures and throughout history. Once deemed a sign of Satan, a potential health risk, and even an illegal product, lipstick has experienced centuries of controversy to secure its status as a marketplace icon - albeit a polarising one. Liberating to some; limiting to others. How have such tensions shaped lipstick's cultural meanings? By examining lipstick's gendered history, we highlight how lipstick reflects contested feminist politics of choice - regarded as playful and deliberately chosen as well as fostering appearance-based expectations based on idealised feminine beauty. We highlight how lipstick gives rise to tensions between empowerment and oppression across three main themes: self-expression and choice, privilege and choice, and morality and choice. We conclude that for lipstick to be pleasurable and freely chosen, it must first be decoupled from patriarchal standards of ideal feminine beauty for women.
\end{abstract}

KEYWORDS: choice feminism, feminine beauty, lipstick, cosmetics, makeup 
Every day, many women spend a significant amount of time applying cosmetics, with nearly 7 in 10 women applying makeup to their lips (Mintel 2019). In turn, this has sustained a multibillion-dollar industry, with the global lipstick market expected to reach $\$ 13.4$ billion by 2024 (P\&S Market Research 2019). Similar to other beauty-related marketplace icons, such as high heels (Parmentier 2016) and shapewear (Zanette and Scaraboto 2019), lipstick is a polarising marketplace icon that is simultaneously associated with both women's autonomy and oppression. Central to this tension is the concept of choice. As Murphy $(2015,17)$ notes, 'a woman's choice is, without a doubt, a central tenet of feminist discourse'. Yet, choice has become an increasingly thorny subject for feminist scholars: some privilege the free exercise of individual choice, whilst others consider how viewing any individual choice as liberating and politically acceptable can obscure the systematic inequalities and patriarchal norms that shape and constrain our choices, as well as downplay the need for collective action (Kiraly and Tyler 2015; Thwaites 2017).

Beauty products and practices are a common focus of this debate in feminist theory, with lipstick being particularly symbolic. For some, the choice to engage in beauty practices is the legacy of feminism and emblematic of women's independence (Lehrman 1997; Walter 1999). Indeed, scholars point to the centrality of women in the development of the cosmetics industry (Peiss 1998) and even position cosmetics as a powerful tool in gender-equitable poverty reduction (Dolan and Scott 2009). Lipstick is named as a pleasurable form of adornment and self-expression that is often maligned, especially in feminist circles (Scott 2005). Versions of third wave feminism that promoted 'girlie culture' considered the reclaiming of feminine symbols like lipstick to be playful and deliberately chosen (Baumgardner and Richards 2004). Colloquially referred to as 'lipstick feminism', this form of feminism displays femininity whilst aware of its patriarchal roots, emphasising that femininity is a positive trait that can be celebrated, such as through one's self-expression with makeup and fashion (Schuster 2017).

Conversely, lipstick as a harmful beauty practice has been subject to a long history of feminist analysis. The wearing of lipstick is conceived as a patriarchal bargain (Kandiyoti 1988), whereby a woman conforms to gender-based rules in order to gain benefit or power from the system. Such a perspective acknowledges that beauty occupies a central role in women's lives (Bartky 1990) due to the importance placed on women's physical appearance and the impetus to conform to unattainable and forever shifting ideals. In turn, this means that beauty work for women is never complete and thus functions as a political weapon against women's advancement (Wolf 1990) Lipstick and beauty culture are thus seen as oppressive and disciplinary, fuelling scrutiny on women's bodies and the alienation of women from their own bodies (Dworkin 1974). Lipstick, a beauty product that has historical links to prostitution (Schaffer 2007), is called out as consuming women's time, energy, money and emotional space - in addition to the health threats its chemicals pose (Jeffreys 2005). The performance of gender through lipstick usage is a lifelong effort, tied to the maintenance of an attractive and respectable appearance (Hurd Clarke and Bundon 2009). Lipstick is thus connected to the production and maintenance of inequality for women and is regarded as a form of oppression as opposed to an individual choice (Bartky 1990; Dworkin 1974; Jeffreys 2005). This is due to the gendered standards that foster expectations for women to comply with beauty standards, 
in turn shaping and constraining women's choices and agency (Baker 2010; Gill 2007; McRobbie 2007; 2009; Stuart and Donaghue 2012).

In this paper, we consider how this contested notion of choice is reflected in three themes related to lipstick as a marketplace icon: self-expression and choice, privilege and choice, and morality and choice. We analyse the evolving history of lipstick and draw upon illustrative examples to demonstrate tensions between oppression and empowerment within each theme. The tensions that emerge reflect how women's personal consumption choices are politicised as they intersect with patriarchal expectations of feminine beauty.

\section{Self-expression and choice: What does lipstick convey?}

The wearing of lipstick is a key signifier of femininity (Brownmiller 1984). This symbolism has given rise to two contested positions within feminist theory. First, that lipstick is a pleasurable, self-chosen and skilled feminine pursuit that should be celebrated (Gimlin 2002), with femininity signifying emancipation and empowerment (Baumgardner and Richards 2004). Here, beauty work becomes an act of agency that enables a woman to gain control of her life and consciously reap rewards (Davis 1995; Dellinger and Williams 1997). Second, that lipstick is a normative and oppressive beauty practice that upholds the narrow feminine ideal, produced and regulated by the lucrative beauty industry that exists at the intersection of capitalism and patriarchy (Bartky 1982; Bordo 1993). Given these structural constraints, lipstick simply serves to reproduce the normative feminine beauty ideal. Consequently, polarised positions of choice as they relate to self-expression and lipstick are presented, with the femininised beauty practice of lipstick conveying possibilities of both oppression and empowerment (Lazar 2011).

The positioning of women's right to feminine self-aestheticisation as an extension of a woman's right to freedom and liberation is strongly associated with a discourse of postfeminism. Postfeminism articulates that the goals of feminism have been achieved, thereby distancing itself from feminist politics of the 'past' - instead highlighting the importance of personal empowerment, sexual agency, pleasure and emancipation (Gill 2007; McRobbie 2009; Negra and Tasker 2007). Beauty work is considered to have multiple layers of meaning and its users should not be portrayed as passive dupes of the patriarchy (Scott 2005). This is reflected in present day narratives around lipstick that suggest it is transformative - the ultimate power accessory to wear to meetings, a bold flourish that commands attention, underlines authority, and bolsters confidence - a foil to insecurity (Felder 2019a). This articulation of 'power femininity' (Lazar 2011) works to suggest that a feminine identity can be powerful, whereby wearing lipstick becomes an assertion of self-determination and agency through the expression of one's individual desires. Power femininity is reflected in two key representations of wearers of lipstick - as heroic or in charge of their sexuality.

The heroic representation of wearing lipstick - particularly red lipstick - as an act of agency can be traced back to the suffragettes. In fighting for women's rights, the suffragettes were portrayed as mannish 'shrieking sisters' who failed to comply with gender norms (Chapman and Nuttall 2011, 253). To dispel such perceptions, the suffragettes sought to present a more feminine appearance, donning delicate white tea dresses with purple and 
green accents - the colours of royalty and growth (Chapman 2015). Yet, as an act of defiance they also wore red lipstick - with the express intent of appalling men due to the historical social proscription of lipstick (Schaffer 2007). Retailers were quick to co-opt red lipstick as a symbol of women's rebellion. Makeup entrepreneur Elizabeth Arden distributed tubes of her 'Red Door Red' lipstick to 15,000 suffragettes as they marched in New York City (Biography.com 2019) and Selfridges became the first British department store to openly display lipstick for sale, targeting suffragettes marching in the streets (Blackman 2018). During World War II, makeup was used to disrupt wartime masculine codes of power (Delano 2000). Red lipstick, which was despised by Adolf Hitler, became a symbol of resilient femininity and patriotism (Goodman 1998; Yesil 2004). This was reflected in the names given to lipsticks, including 'Fighting Red!', 'Patriot Red!' and 'Grenadier Red!'. Even wartime propaganda posters, like the iconic Rosie the Riveter image, depicted women with soft red lipstick. Lipstick was also used to boost morale, with the bathrooms of munitions factories in which women worked stocked with red lipsticks such as Elizabeth Arden's 'Victory Red' to foster worker efficiency (see figure 1).

Figure 1. Elizabeth Arden advertisements (1941-1942) for patriotic Victory Red lipstick.
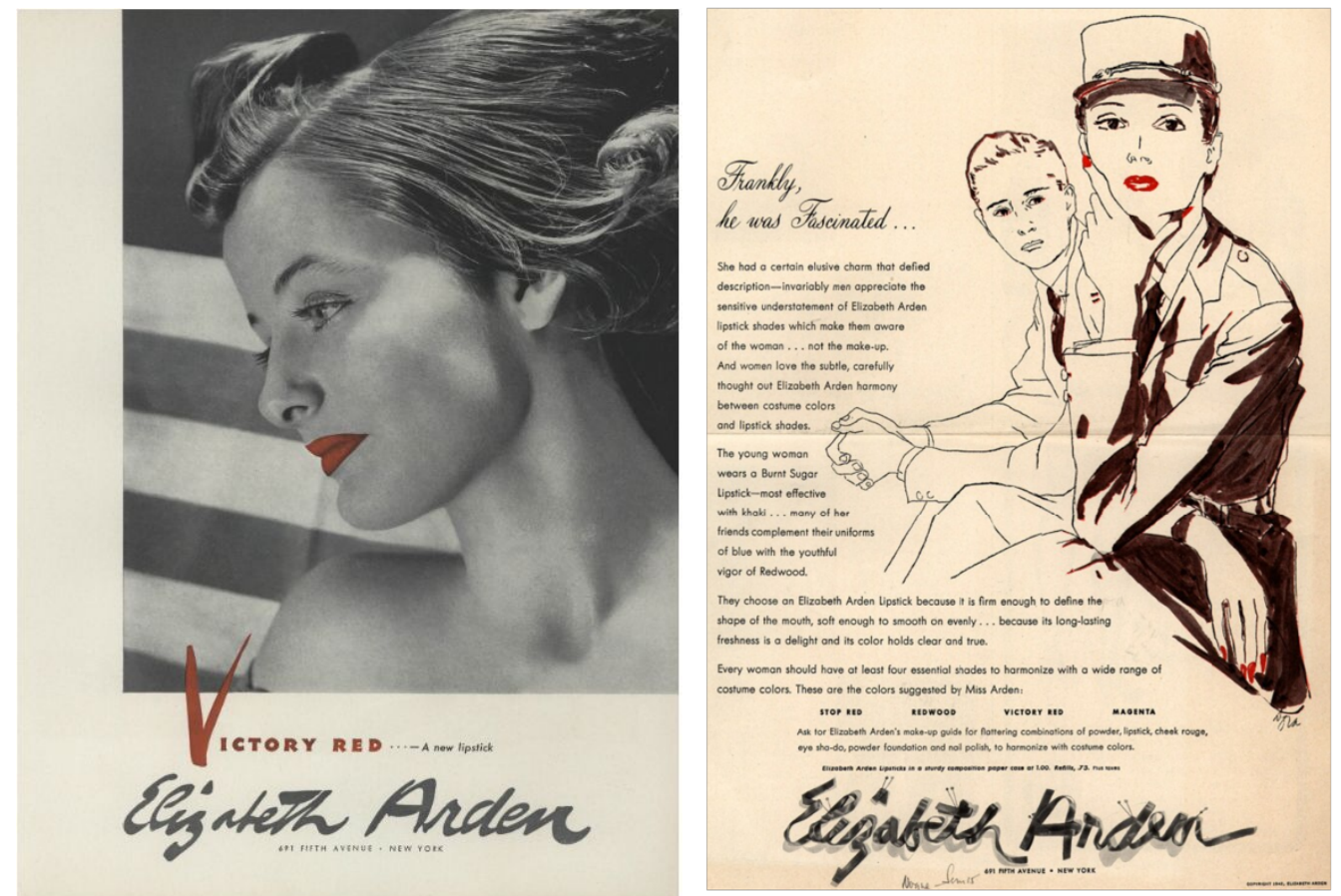

Sources: HPrints; Duke University Libraries AdAccess

The representation of lipstick wearers as in charge of their sexuality was first made through associations with Hollywood 'bad girls' and 'sex symbols', such as Mae West - a sexually uninhibited working class woman who flaunted a raunchy streetwise style with her signature 'cupie-bow' red lipstick (Hamilton 1997). The desirability of red lipstick was further enhanced by the bold lips of 'bombshell' actresses such as Elizabeth Taylor and Marilyn Monroe. Hence, empowerment becomes signalled through a woman being in control of her 
body and the pleasures of that body (Wolf 1990). The marketing of lipstick as something that a woman wore for her own pleasure and satisfaction was first enacted in Revlon's Fire and Ice advertisement that asked of women, 'Are you made for Fire and Ice?', with the face of the brand Dorian Leigh posed confidently yet seductively, clad in a fitted, sparkling dress, with bright red lips and without a man in sight (see figure 2). A quiz accompanying the image asked its female readers questions such as 'Do you blush when you find yourself flirting?' and 'Do you close your eyes when you are kissed?' to determine if they were 'naughty' or 'nice'. Such a representation sought to spark the imagination of women to explore both their demure and daring sides. In this way, lipstick came to symbolise something that a woman could wear to please herself and explore her sexuality (Tungate 2011), as a sexually autonomous, active and desiring subject (Gill 2003). Today, lipstick continues to be touted as a sign of empowerment and sexual autonomy for women. Advertorials promoting modern red lipstick suggest the "trick to red lipstick's power is to 'own' wearing it - to find the one that's right for you and know it's the ultimate accentuator of feminine strength" (Felder 2019b, n.p.). Many lipsticks today are named in relation to sex and romance, such as 'Desire', 'Passion', 'Lust', 'Foreplay' and 'Long Kiss' (Merskin 2007), signalling the reclamation of women's sexual desire and celebrating their sexual agency.

Figure 2. Revlon's (1952) 'Fire and Ice' advertisement.

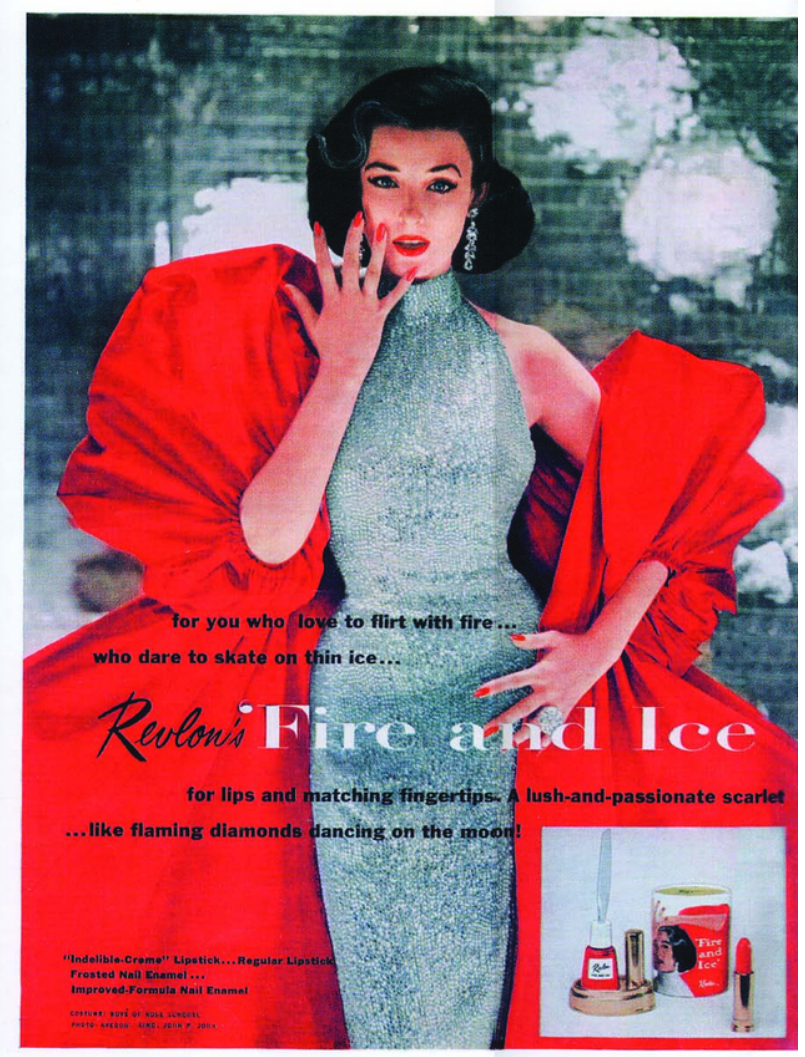

Source: Revlon 
Yet, feminist critics argue that such an emancipated femininity is both reliant on and supported by consumer culture. Women are constrained to attain (often de-politicised) feminist goals through their consumption choices (Goldman 1992; Lazar 2011). Cosmetics, such as lipstick, are furthermore viewed as tools of patriarchal capitalism designed to gain women's consent to their own oppression (Merskin 2007). The beauty industry is considered so opportunistic that even the resistant act of not wearing makeup is appropriated and reinterpreted in the form of the 'natural look', something still to be achieved through cosmetics use (Black 2004). The beauty industry conditions women to focus on and constantly work to change their appearance in pursuit of achieving the hegemonic feminine ideal, in turn driving an unhealthy preoccupation with body image (Bartky 1982; Bordo 1993; Dworkin 1974). This reinforces both the value of physical attractiveness for women and the imperative that women's bodies must be altered as their natural state is unacceptable. As Jeffreys (2005, 114) poses, "Women may well say makeup empowers them but the interesting question is, what disempowers them about being without their mask?" She highlights how the political structures of patriarchy that reinforce such ideals and expectations foster women's discomfort in being barefaced in public. Hence, in spite of the postfeminist promises of liberation through choice - often exercised through the marketplace - much of the traditional gender order remains undisturbed. Such an 'emphasised femininity' that reinforces the centrality of appearance for girls and women is thus both complicit to gender inequality and organised around the desires and interests of men (Connell 1987). Striving to attain the feminine ideal, through beauty practices such as lipstick, functions to both control women and ensure the maintenance of existing power relations (McRobbie 2015).

\section{Privilege and choice: Who can wear lipstick?}

Taking an intersectional approach (Crenshaw 2015) to understanding women's beauty practices in relation to the marketplace provides another means of interrogating the oppositional choice positions associated with lipstick. In feminist theory, intersectionality highlights how systems of oppression intersect with multiple identities and hierarchies of social stratification, such as race, sexuality, and age (Carastathis 2014). This is reflected in the patterns of underrepresentation and misrepresentation of marginalised groups in marketing images, leading to a plethora of young, lean, heterosexual and light-skinned representations (Gopaldas and Siebert 2018). Thus, on the one hand, the question of 'who can wear lipstick' prompts consideration of how privilege has functioned against women that do not fit this ideal. On the other hand, over time entrepreneurs have opened up the choice of beauty products, such as lipstick, to these same marginalised groups, thus challenging both marketplace exclusion and the mandated beauty ideal.

Lipstick has historically been associated with ideal female beauty (Merskin 2007), offering the promise of enhancing one's features to reflect the feminine ideal (Bloch and Richins 1992). Yet, beauty ideals embrace youth and privilege whiteness (Bordo 1993; Collins $1991 ; 2004 ;$ M. C. Jones and Shorter-Gooden 2003), with such idealised beauty heavily represented in advertising that seeks to confer such status on beauty products (Redmond 
2003). This speaks to how lipstick has functioned as a tool of oppression, not only in terms of sexism, but also racism and ageism. In the production of 'normative femininity' (Bartky 2003), beauty practices like lipstick function to produce a recognisably feminine appearance that embodies dominant cultural ideals. This was reflected in the globalisation of the beauty industry between 1945 and 1980, which significantly narrowed the range of variation in beauty ideals (G. Jones 2008). Iconic lipstick advertisements have long reflected this white, youthful ideal. For example, in the late 1920s, Phantom Red lipstick boomed in popularity.

Advertisements featured Phantom of the Opera star, Mary Philbin, as an 'angelic child-woman' promising natural, youthful looking beauty (V. Jackson and Lameris 2014, 21). Throughout the early to mid $20^{\text {th }}$ century, lipstick advertisements for companies like Tangee, Westmores of Hollywood, and Max Factor, featuring white celebrities, highlighted how their lipstick shades perfectly complement 'delicate', 'English' complexions to maintain a 'youthful', 'bright', and 'young' appearance. Such rhetoric and visual imagery reinforced prevailing feminine beauty ideals and propagated colourism and ageism.

The marketing of lipstick as representing and for white women meant that access to cosmetic products was historically difficult for women of colour. For example, in the Jim Crowera United States, where segregation was the norm, black women could not walk up to cosmetics counters at large department stores; rather, they were limited to purchasing beauty products through direct selling or mail-order advertisements (Nittle 2018). The first makeup company that targeted black women, Overton-Hygienic, was created in 1898 by AfricanAmerican entrepreneur Anthony Overton. Overton also created one of the first physical stores for women of colour to shop for cosmetics (Baldwin 2003). However, his trademark 'highbrown' face powder contained skin-lightening elements, thus adhering to the privileging of white skin (Keith and Monroe 2016). Another skin lightening powder called Valmor's Sweet Georgia Brown was created in 1926 by a white entrepreneur who hired two black artists, Charles Dawson and Jay Jackson, to design advertisements for the product. The artists aimed to 'depict African Americans with dignity' rather than 'racial caricatures with funhouse facial features' (Nittle 2018). They created pop-art illustrations of ethnically ambiguous women wearing bright red lipstick (see figure 3 ). Red lipstick was thus coupled with skin lightening powder in advertisements targeting women of colour in the segregationist era (Walker 2007). In this way, red lipstick became a means to emulate the feminine ideals of beauty in white consumer culture and was positioned as a pathway toward respectability, mirroring the politics of 'proper' comportment among African-American consumers to manage racial stigma (Crockett 2017). 
Figure 3. Red lipstick featured in advertisement for Valmor's Sweet Georgia Brown Face Powder.

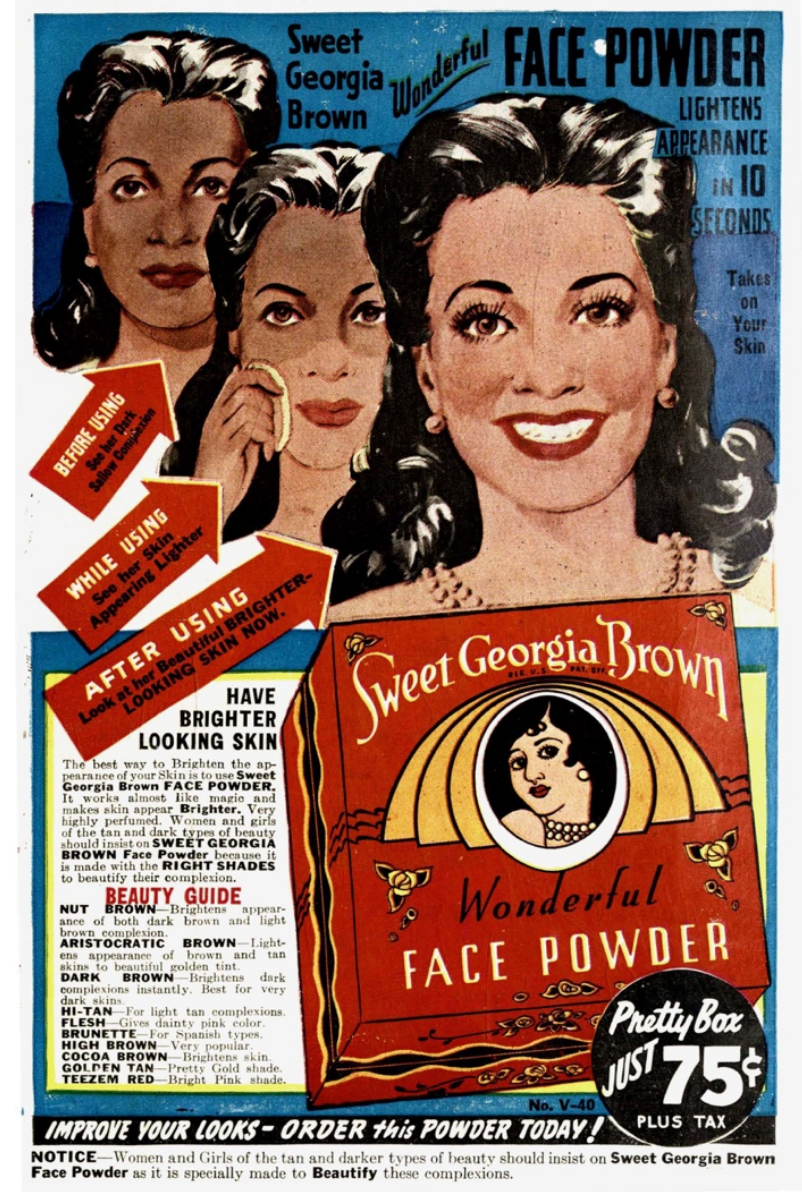

Source: Swarthmore College Libraries Conjure Americana Collection

Though cosmetics became more accessible to women of colour in the marketplace, these choices were fraught. Marketplace offerings for women of colour continued to lag until black owned brands like Fashion Fair hit the market in the 1970s followed by brands like Black Opal and IMAN Cosmetics in the 1990s. These entrepreneurial efforts by African-American women not only built their economic self-sufficiency but also challenged beauty standards anchored in whiteness that had historically excluded women of colour from the marketplace (Peiss 1998; Walker 2007). For instance, in the beauty industry, 'flesh tone' defaults to white or light skinned flesh (Hunter 2013; Tate 2017) and perceptions of 'nude lipstick' are embedded in structural systems of racial inequality (Burns 2017). Black women report struggling to find 'nude' or 'natural' lipstick colours to complement their complexions among market offerings from mainstream mass-marketed and luxury brands (Mintel 2018); however, the market is slowly changing. Barbadian singer/celebrity Rihanna's Fenty Beauty brand is credited with disrupting the modern beauty industry by designing more racially inclusive lip colours to complement an array of skin tones. Additionally, the line has been promoted by a diverse and 
inclusive range of women (Miranda 2017). Mented, which is short for pigmented, was founded by KJ Miller and Amanda E. Johnson, two African-American women who were both frustrated with the inability to find nude lipstick (Rogers and Mills 2017). Mented launched with six nude and neutral lipsticks designed for deeper skin tones-as the co-founders note, "the basis of a clean beauty look is a nude lipstick, which we just couldn't find anywhere-we don't all have pink lips" (Mented Cosmetics 2017). Lipstick acts as an extension of multiracial consumer identity in the marketplace (Harrison, Thomas, and Cross 2015) as these market-based opportunities to embrace a various beauty looks support women of colour in challenging normative beauty standards (e.g., natural hair movement; Ndichu and Upadhyaya 2019). Similar to other industries in which consumers face marketplace marginalisation (e.g. fatshionistas; Scaraboto and Fischer 2013), mainstream marketers are slow to offer acceptable diverse lipstick products and market change is increasingly a result of upstarts created by women of colour. Such representation and choice is critical for women of colour and multiracial consumers who have been historically stereotyped, tokenised and ignored by mainstream beauty brands (Harrison, Thomas, and Cross 2015) and reflects a history of women's black-owned beauty businesses stimulating social change (Gill 2010; Harvey 2005).

Similarly, ageism is rampant in the beauty industry, wherein lipstick is marketed as a pathway to a more youthful appearance. Older women engage in beauty work to combat the experience of physical and social invisibility in a youth obsessed culture (Hurd Clarke and Griffin 2008). Lipstick, in particular, plays a key role in tethering women to a youthful identity despite the realities of growing older. In interviews with 71-93 year old women, Hurd Clarke and Bundon (2009) find that putting on lipstick is an important practice in older women's beauty routines to achieve a feminine and culturally 'respectable' appearance. Yet, the choice to wear lipstick is fraught with tensions between conforming to versus confronting youthful feminine beauty ideals. Aging women's 'choices are ultimately determined in a world where to challenge ageist stereotypes is to run the risk of further stigmatization and permanent invisibility' (Hurd Clarke and Griffin 2008, 671). In more recent times, we have witnessed greater inclusion of women aged over 50 in beauty culture. For example, in 2017, 69-year-old Maye Musk was named as a CoverGirl brand ambassador for the 'I am what I makeup' campaign (Safronova 2017; see figure 4). In 2012, fashion icon Iris Apfel, aged in her 90s, collaborated with MAC Cosmetics to produce a line of 'unapologetically bold' lipsticks (Murrow 2012). Greater representation of older (though usually white) women, both in the marketing for and creation of lipstick, represents a step toward upending ageist notions of beauty while potentially reinforcing the body work required to remain visible and thereby valued in the marketplace. 
Figure 4. CoverGirl brand ambassador Maye Musk (left) with senior vice president of CoverGirl, Ukonwa Ojo (center), and CoverGirl brand ambassador, Ayesha Curry (right)

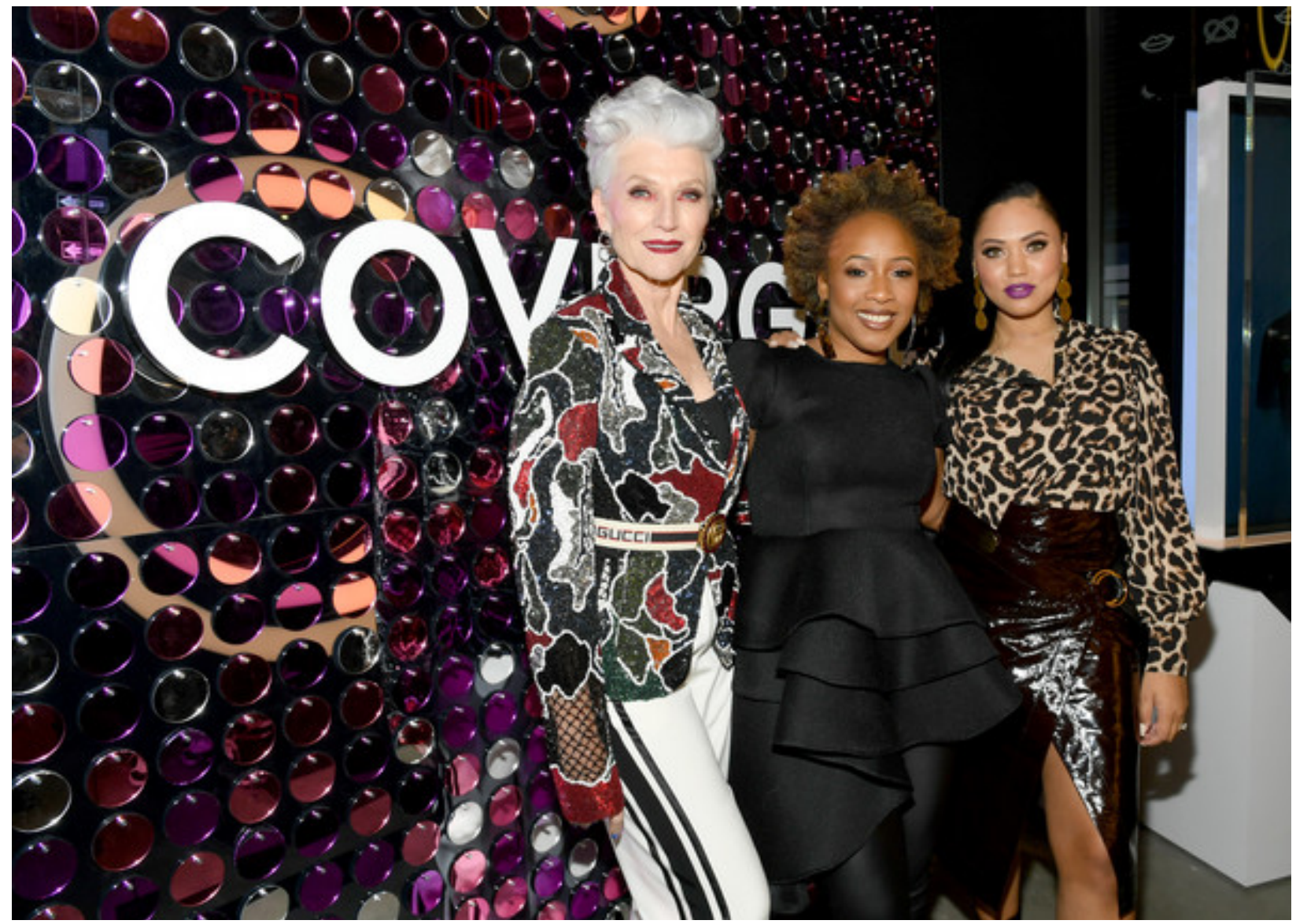

Source: Mike Coppola/Getty Images North America

Whilst greater diversity in terms of race and age in lipstick marketing presents an important challenge to narrow beauty ideals, it is important to note the women chosen as the faces of this diversity still often conform to or reinforce mainstream standards. For example, Young (1999) notes that black beauty models tend to have faces and bodies that still conform to dominant ideals of white beauty whilst hooks (1992) and Williamson (1986) argue that ethnic models can be used to convey exoticism, which in turn serves to normalise and entrench white beauty standards. Hence, privilege in beauty culture operates by imposing constraints on those who do not fit the dominant ideal, historically resulting in their exclusion. Yet, these same dynamics open up opportunities for both economic and political resistance.

\section{Morality and choice: What rules exist for lipstick?}

Through a contested feminist lens of choice, lipstick can be viewed as a marker of morality (Beausoleil 1994; Peiss 1998; Smith 1990), which has worked to establish gendered norms and proscriptions that mitigate the wearing of lipstick. Historically, this reflected the casting of lipstick wearers as sexually immoral and the incantation of Satan (Cohen Ragas and 
Kozlowski 1998). Today, the use of lipstick continues to be mandated through restricted access and dress/grooming standards that problematise an account of women freely exercising their individual choices by highlighting the constraints of patriarchal norms. Yet, in response to the (oft contradictory) rules constructed about lipstick are varied acts of resistance, ranging from the everyday, to the collective and the institutionalised.

Prior to the 1920s, lipstick in the Western world was something 'nice girls' did not wear (Merskin 2007). Women refrained from wearing lipstick due to religious beliefs, ethnic cultural traditions and concepts of respectability (Peiss 1990). There was a strong association between lipstick and prostitution (e.g. 'painted ladies') and a belief that altering one's face interfered with the handiwork of God (Pallingston 1999). Consequently, both state and church regulated lipstick usage and governed women's appearances. In the late 1700s, the British Parliament passed a law condemning lipstick, stating that 'women found guilty of seducing men into matrimony by a cosmetic means could be tried for witchcraft' (Cohen Ragas and Kozlowski $1998,17)$. Lipstick was condemned as 'the Devil's candy' due to popular beliefs it contained 'lifesaving' magical powers (Schaffer 2007), with women frequently having to address their sinful lipstick usage at confession (Pointer 2005). This stigma of sexual immorality for lipstick has both historical and present-day associations. In Ancient Greece and Victorian England, red lip colouring was mandated for use by prostitutes to distinguish them from 'respectable' and 'virtuous' women (Schaffer 2007). The term 'lipstick girls' is used around the world today as a term for prostituted women (Butt 2005; Siegel and Yesilgoz 2003). And lipstick continues to be regulated by governments. For example, in North Korea women can only choose from a stipulated selection of 'appropriate' makeup that limits the use of lipstick. Indeed, North Koreans do not have a word for lipstick (Lebsack 2019). In these ways, lipstick is a product that reproduces systematic inequalities and gendered expectations that shape and constrain both women's choices and lives.

Dress codes and grooming policies further moralise and regulate lipstick, functioning as gendered forms of social control that determine what is 'acceptable' and 'appropriate' in a given context. Moreover, such standards tend to reflect wider gender norms. Women are expected to attend to a multiplicity of dress and appearance details and are acutely aware of the importance attached to the decision to wear makeup and the style and amount of makeup chosen (Ainsworth 2014). For example, not wearing lipstick at work may be seen as a rejection of conventional 'appropriate' femininity (Merskin 2007). Dress codes and grooming policies in workplaces overwhelmingly require women to undertake more extensive aesthetic labour, in turn centring the importance of their appearance (Witz, Warhurst, and Nickson 2003). In the service sector, bartenders and restaurant servers can be required to adopt a highly feminised and sexualised appearance (Brower, Jones, and Brower 2013; Warhurst and Nickson 2009) that necessitates lipstick. For example, Emirates airlines requires its flight attendants to wear a specific shade of 'Emirates red' lipstick to match the brand's red color, as mandated by the company's Imaging and Grooming Department and learned through the company's 'skygirls' training program (see figure 5; Feldman 2017). In schools, lipstick is often prohibited or restricted, thereby creating boundaries in relation to proper and improper femininity for girls. This reflects wider cultural anxieties and moral panics about girls' sexualities and the importance attached to 'good girl' femininity (Jackson and Vares 2011). In contrast, 
traditionally feminised leisure activities, such as dance recitals and pageants, instruct girls to wear lipstick to perform femininity from a young age (Oppliger 2008). In prisons, lipstick functions to both moralise and exploit women. In American prisons, lipstick is contraband but highly desired by female inmates, making it ripe to be a form of sexual exploitation by male prison guards. In Russia, annual 'lipstick and lace' beauty pageants are held in which prisoners are required to wear makeup, perform domestic duties and demonstrate traditional 'passive' feminine virtues (Moran, Pallot, and Piacentini 2009). These examples highlight how gendered standards mitigate the wearing of lipstick, that in turn work to oppress women by moralising and controlling their bodies.

Figure 5. Emirates flight attendant practising mandated lipstick requirements.

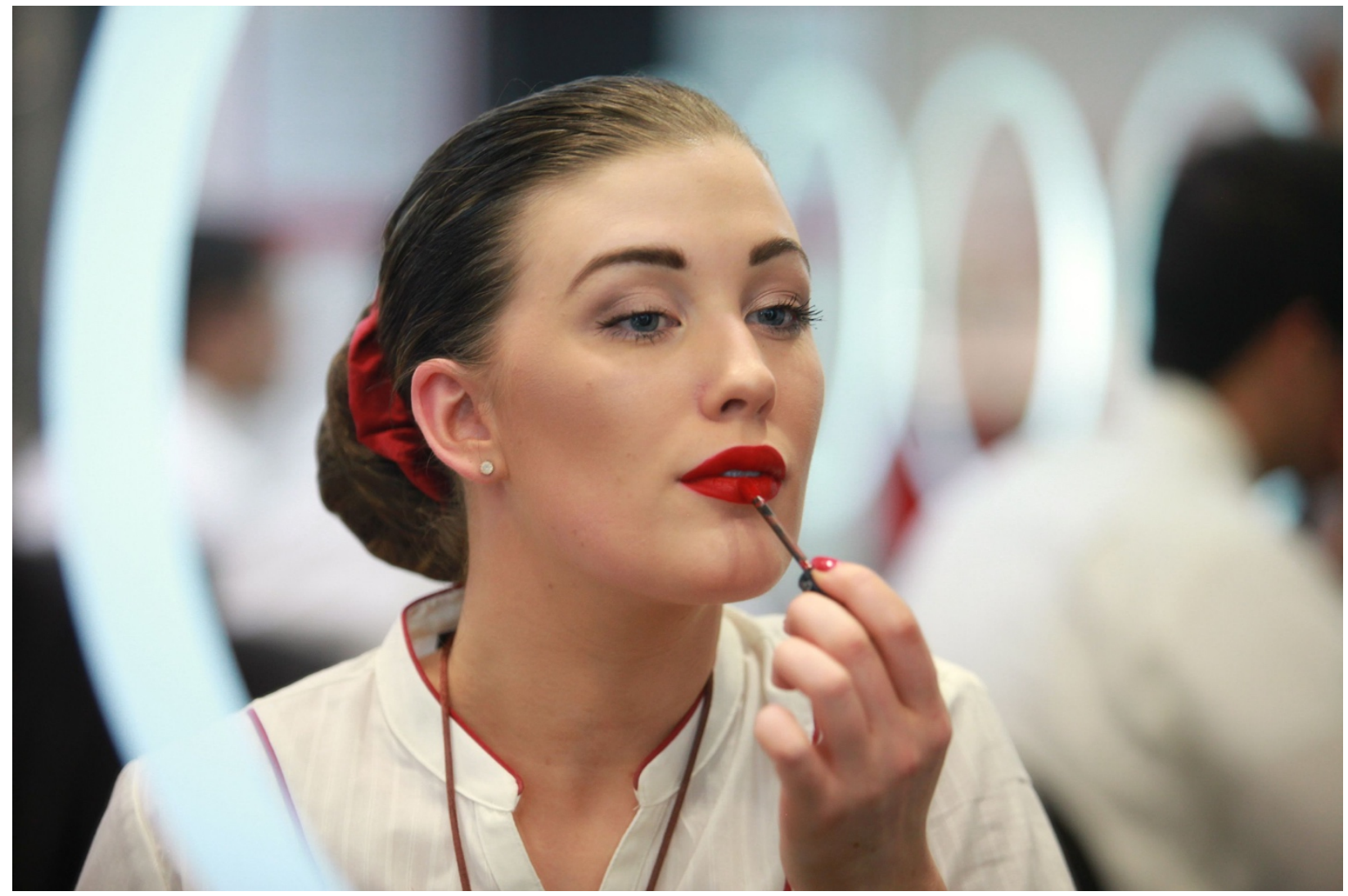

Sources: Emirates

Yet, feminist scholars also highlight how lipstick has been employed to resist and challenge gendered norms, becoming a tool of political engagement and activism to revise societal rules and foster social change. These acts of resistance range from the everyday, to the collective to the institutionalised. Historical prohibitions against lipstick - whether legal or due to social stigmatisation - simply drove the beauty practice underground, with women devising do-it-yourself alternatives, including pressing lips into red crepe paper, licking lips with red ribbons and complex homemade concoctions (Cohen Ragas and Kozlowski 1998; Schaffer 2007). This highlights the complexity of women's engagements in beauty practices and the importance of treating women as active and knowledgeable agents (Fisher and Davis 
1993) and not cultural dupes who have had 'the ideological wool pulled over their eyes' (Davis $1995,57)$. For example, Dellinger and Williams' (1997) analysis of women's use of makeup at work highlights how women can assert authority within institutional constraints by negotiating rules and transforming the meanings attached to makeup that reflect their creativity and pursuit of bodily pleasure. What was considered 'acceptable' for lipstick usage was further challenged by the glam rock, punk rock, goth and new romantic music subcultures that actively questioned and challenged gender norms. Male singers wore and experimented with makeup, for example the glossy and metallic lips of David Bowie's Ziggy Stardust and Robert Smith of The Cure's smeared red lips, in turn challenging social conventions and the rules of who should wear lipstick and how it should be worn.

Figure 6. The original advertisement for MAC Cosmetics' VIVA GLAM campaign (1994) featuring drag queen, RuPaul

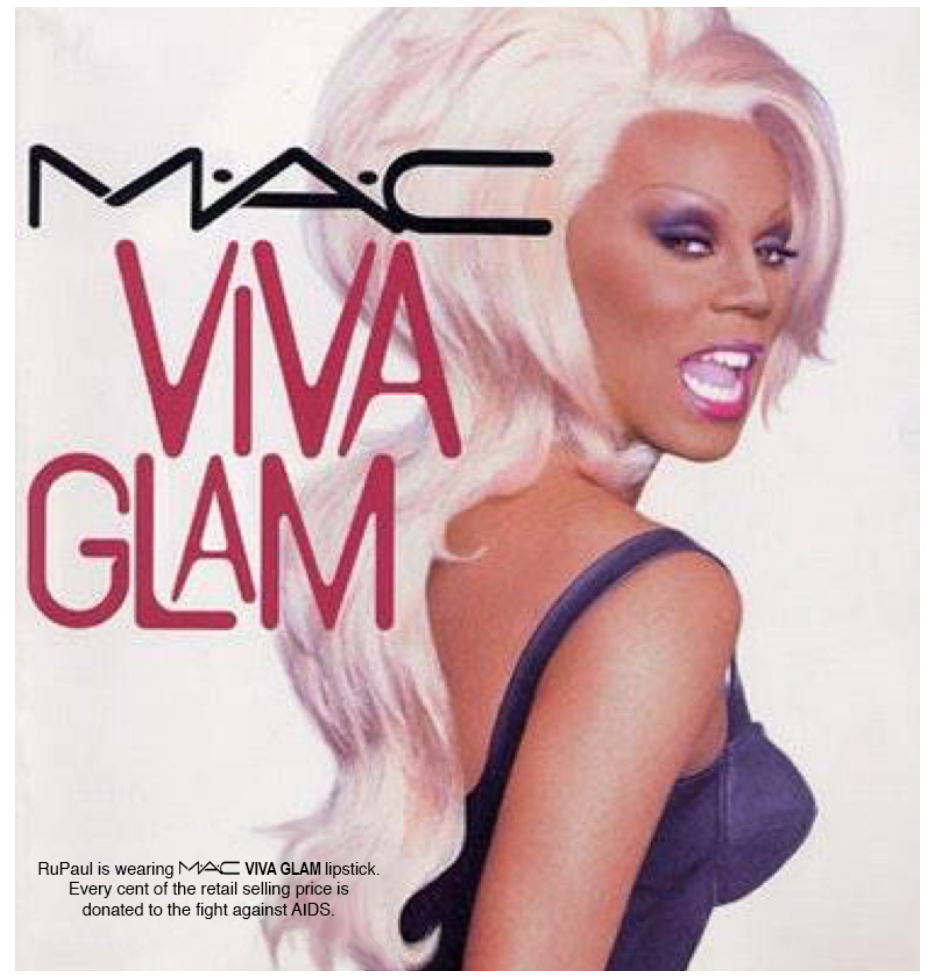

Source: MAC Cosmetics

Lipstick has also been used as a vehicle to further social issues and causes, in turn shifting ideas of what is considered 'right' and 'wrong' in relation to the product. In 1994, drag queen RuPaul served as the spokesperson for MAC Cosmetics' VIVA GLAM lipstick, a product created to support people living with HIV/AIDS (see figure 6). As the first drag queen to land a major cosmetics campaign, RuPaul paved the way for mainstreaming drag culture and challenging the informal regulation of lipstick as a female activity. The product also made an important cultural statement against the larger backdrop of stigmatised and vitriolic narratives about HIV/AIDS, driving social change by changing the conversation from death to celebrating life full of glamour, humour and creativity (Benoit 2013). As Hurd Clarke and Bundon (2009, 
212) note, "although a seemingly trivial act, wearing lipstick is a powerful example of how the personal is political." Lipstick manufacturers continue to intersect political and social issues, recently aligning with key social movements related to gender inequality. For example, iconic 90s brand Hard Candy attempted to trademark the \#MeToo hashtag while the brand LipSlut sells lipstick shades 'F*ck Kavanaugh' and 'F* ck Hollywood' in the wake of recent scandals and allegations, donating proceeds to support women's reproductive health and anti-sexual assault organisations (Boan 2018). Yet, this feminist solidarity continues to be coupled with messaging that asserts lipstick enables women to be more beautiful - and that this is something they should always be striving for. Some rules, it seems, are not meant to be broken.

\section{Conclusion}

In his 1894 essay, A Defence of Cosmetics, humourist Max Beerbohm offered a tonguein-cheek claim that makeup might successfully deter women from pursuing more masculine endeavours, such as sports or careers (Beerbohm 1922). Yet, the beauty industry has provided ongoing employment opportunities for women - indeed between 1890 and 1920 it was almost completely woman-run (Peiss 1998) - and has spawned numerous female entrepreneurs including Helena Rubinstein, Elizabeth Arden, Bobbi Brown and more recently Kylie Jenner. Despite the crucial role of women in the beauty industry, this does not negate the oppressive role of feminine beauty ideals for women. In articulating how lipstick has continually intersected with the feminist politics of choice throughout history, we demonstrate lipstick's status as a marketplace icon.

First, in analysing lipstick as it relates to self-expression and choice, we illustrate tensions between lipstick as a playful and empowering beauty practice that should be celebrated versus lipstick as a normative and oppressive feminine ideal rooted in patriarchal expectations. Second, in analysing lipstick as it relates to privilege and choice, we illustrate tensions between lipstick as an exclusionary practice that reinforces vitriolic standards of beauty (e.g., colorism, ageism) versus lipstick as a pathway toward entrepreneurial market change for and by those historically marginalised in the mainstream beauty industry. Third, in analysing lipstick as it relates to morality and choice, we illustrate tensions between lipstick as a beauty practice mandated by strict systematised rules of governing its access and application versus lipstick as an act of social and political resistance challenging gendered norms.

Given that beauty serves as a controlling and time-consuming force in many women's lives, the fact some women 'choose' to wear lipstick does not detract from its role in perpetuating gendered inequalities and producing docile feminine bodies (Bartky 1990; Bordo 1993). As Cahill $(2003,42)$ observes, "the empowering characteristics of beautification, however, are difficult and perhaps impossible to represent in a sexist context; therefore, while beautifying may be a positive experience for women, being viewed as a beautified object in current Western society is almost always opposed to women's equality and autonomy." Hence, for lipstick to be pleasurable and freely chosen for women, we conclude it must first be decoupled from patriarchal standards of ideal feminine beauty for women. 


\section{References}

Ainsworth, Janet. 2014. "What's Wrong with Pink Pearls and Cornrow Braids? Employee Dress Codes and the Semiotic Performance of Race and Gender in the Workplace." In Law, Culture and Visual Studies, edited by Anne Wagner and Richard K. Sherwin, 241-60. Dordrecht: Springer Netherlands.

Baker, Joanne. 2010. "Claiming Volition and Evading Victimhood: Post-Feminist Obligations for Young Women." Feminism \& Psychology 20 (2): 186-204.

Baldwin, Davarian L. 2003. "Chicago's New Negroes: Consumer Culture and Intellectual Life Reconsidered." American Studies 44 (1/2): 121-52.

Bartky, Sandra Lee. 1982. "Narcissism, Femininity and Alienation." Social Theory and Practice 8 (2): 12743.

Bartky, Sandra Lee. 1990. Femininity and Domination: Studies in the Phenomenology of Oppression. Psychology Press.

Bartky, Sandra Lee. 2003. "Foucault, Femininity, and the Modernization of Patriarchal Power." In The Politics of Women's Bodies: Sexuality, Appearance, and Behavior, edited by Rose Weitz, 2nd ed., 25-45. Oxford University Press.

Baumgardner, Jennifer, and Amy Richards. 2004. "Feminism and Femininity: Or How We Learned to Stop Worrying and Love the Thong." In All about the Girl: Culture, Power, and Identity, edited by Anita Harris, 59-67. Psychology Press.

Beausoleil, Natalie. 1994. "Make-up in Everyday Life: An Inquiry into the Practices of Urban American Women of Diverse Backgrounds." In Many Mirrors: Body Image and Social Relations, edited by Nicole Landry Sault, 33-57. Rutgers University Press.

Beerbohm, Max. 1922. A Defence of Cosmetics. New York: Dodd, Mead and Company. http://archive.org/details/defenceofcosmeti00beer.

Benoit, Andrea. 2013. "'"From Our Lips:" Lipstick as Consumer Technology and the MAC VIVA GLAM Advertising Campaigns.'" Scientia Canadensis 36 (1): 111-32.

Biography.com. 2019. "Elizabeth Arden." Biography. June 18, 2019. https://www.biography.com/business-figure/elizabeth-arden.

Black, Paula. 2004. The Beauty Industry: Gender, Culture, Pleasure. Routledge.

Blackman, Cally. 2018. "How the Suffragettes Used Fashion to Further Their Cause." Stylist. February 6, 2018. https://www.stylist.co.uk/fashion/suffragette-movement-fashion-clothes-what-did-thesuffragettes-wear/188043.

Bloch, Peter H., and Marsha L. Richins. 1992. "You Look 'Mahvelous': The Pursuit of Beauty and the Marketing Concept." Psychology \& Marketing 9 (1): 3-15. 
Boan, Daniel. 2018. "A lipstick brand released a new shade called F*ck Kavanaugh — and 100\% of the proceeds go towards organizations fighting sexual assault." INSIDER. October 1, 2018. https://www.insider.com/kavanaugh-lipslut-lipstick-sexual-assault-organization-2018-10

Bordo, Susan. 1993. Unbearable Weight: Feminism, Western Culture, and the Body. University of California Press.

Brower, Todd, Jackie Jones, and Todd Brower. 2013. "What's in the Closet: Dress and Appearance Codes and Lessons from Sexual Orientation." Equality, Diversity and Inclusion: An International Journal, June.

Brownmiller, Susan. 1984. Femininity. Linden Press/Simon \& Schuster.

Burns, Edgar A. 2017. "Ethic of Discomfort: Is Asking for Nude Lipstick Racist?" Race Ethnicity and Education, December. https://www.tandfonline.com/doi/pdf/10.1080/13613324.2017.1417250.

Butt, Leslie. 2005. "'Lipstick Girls' and 'Fallen Women': AIDS and Conspiratorial Thinking in Papua, Indonesia." Cultural Anthropology 20 (3): 412-42.

Cahill, Ann J. 2003. "Feminist Pleasure and Feminine Beautification." Hypatia 18 (4): 42-64.

Carastathis, Anna. 2014. "The Concept of Intersectionality in Feminist Theory." Philosophy Compass 9 (5): 304-14.

Chapman, Jane. 2015. "The Argument of the Broken Pane." Media History 21 (3): 238-51.

Chapman, Jane, and Nick Nuttall. 2011. Journalism Today: A Themed History. John Wiley \& Sons.

Cohen, Patricia. 2006. "Today, Some Feminists Hate the Word 'Choice.'" The New York Times, January 15, 2006, sec. Week in Review. https://www.nytimes.com/2006/01/15/weekinreview/todaysome-feminists-hate-the-word-choice.html.

Cohen Ragas, Meg, and Karen Kozlowski. 1998. Read My Lips: A Cultural History of Lipstick. Chronicle Books.

Collins, Patricia Hill. 1991. Black Feminist Thought: Knowledge, Consciousness, and the Politics of Empowerment. Routledge.

Collins, Patricia Hill. 2004. "Very Necessary: Redefining Black Gender Ideology." In Black Sexual Politics: African Americans, Gender, and the New Racism, 181-212. Routledge.

Connell, Raewyn. 1987. Gender and Power: Society, the Person, and Sexual Politics. Stanford University Press.

Crenshaw, Kimberle. 2015. "Demarginalizing the Intersection of Race and Sex: A Black Feminist Critique of Antidiscrimination Doctrine, Feminist Theory and Antiracist Politics." University of Chicago Legal Forum 1989 (1). https://chicagounbound.uchicago.edu/uclf/vol1989/iss1/8. 
Crockett, David. 2017. "Paths to Respectability: Consumption and Stigma Management in the Contemporary Black Middle Class." Journal of Consumer Research 44 (3): 554-81.

Davis, Kathy. 1995. Reshaping the Female Body: The Dilemma of Cosmetic Surgery. Routledge.

Delano, Page Dougherty. 2000. "Making Up for War: Sexuality and Citizenship in Wartime Culture." Feminist Studies 26 (1): 33-68.

Dellinger, Kirsten, and Christine L. Williams. 1997. "Makeup at Work: Negotiating Appearance Rules in the Workplace." Gender \& Society 11 (2): 151-77.

Dolan, Catherine, and Linda Scott. 2009. "Lipstick Evangelism: Avon Trading Circles and Gender Empowerment in South Africa." Gender \& Development 17 (2): 203-18.

Dworkin, Andrea. 1974. Woman Hating. Plume.

Felder, Rachel. 2019a. Red Lipstick: An Ode to a Beauty Icon. HarperCollins.

Felder, Rachel. 2019b. "The Undeniable Power of Red Lipstick." Good Housekeeping. July 8, 2019. https://www.goodhousekeeping.com/uk/fashion-beauty/a28183150/red-lipstick-meaninghistory-power/.

Feldman, Jamie. 2017. "Emirates Airlines Flight Attendants Reveal Just How Much Goes Into Their InFlight Look." Huffington Post. December 7, 2017. https://www.huffpost.com/entry/emiratesflight-attendants_n_5999818

Fisher, Sue, and Kathy Davis. 1993. Negotiating at the Margins: The Gendered Discourses of Power and Resistance. Rutgers University Press.

Gill, Rosalind. 2003. "From Sexual Objectification to Sexual Subjectification: The Resexualisation of Women's Bodies in the Media." Feminist Media Studies 3 (1): 100-106.

Gill, Rosalind. 2007. "Critical Respect: The Difficulties and Dilemmas of Agency and 'Choice' for Feminism: A Reply to Duits and van Zoonen." European Journal of Women's Studies 14 (1): 6980.

Gill, Tiffany M. 2010. Beauty Shop Politics: African American Women's Activism in the Beauty Industry. University of Illinois Press.

Gimlin, Debra. 2002. Body Work: Beauty and Self-Image in American Culture. University of California Press.

Goldman, Robert. 1992. Reading Ads Socially Routledge.

Goodman, Phil. 1998. "'Patriotic Femininity': Women's Morals and Men's Morale During the Second World War." Gender \& History. July 1, 1998. 
Gopaldas, Ahir, and Anton Siebert. 2018. "Women over 40, Foreigners of Color, and Other Missing Persons in Globalizing Mediascapes: Understanding Marketing Images as Mirrors of Intersectionality." Consumption Markets \& Culture 21 (4): 323-46.

Hamilton, Marybeth. 1997. "When I'm Bad, I'm Better": Mae West, Sex, and American Entertainment. University of California Press.

Harrison, Robert L., Kevin D. Thomas, and Samantha N. N. Cross. 2015. "Negotiating cultural ambiguity: the role of markets and consumption in multiracial identity development." Consumption Markets \& Culture. 18 (4): 301-332.

Harrison, Robert L., Kevin D. Thomas, and Samantha N. N. Cross. 2017. "Restricted Visions of Multiracial Identity in Advertising." Journal of Advertising. 46 (4): 503-520.

Harvey, Adia M. 2005. "Becoming entrepreneurs: Intersections of race, class, and gender at the black beauty salon." Gender \& Society 19 (6): 789-808.

hooks, bell. 1992. Black Looks: Race and Representation. Between The Lines.

Hunter, Margaret L. 2013. Race, Gender, and the Politics of Skin Tone. Routledge.

Hurd Clarke, Laura, and Andrea Bundon. 2009. "From 'The Thing to Do' to 'Defying the Ravages of Age': Older Women Reflect on the Use of Lipstick." Journal of Women \& Aging 21 (3): 198-212.

Hurd Clarke, Laura, and Meridith Griffin. 2008. "Visible and Invisible Ageing: Beauty Work as a Response to Ageism." Ageing \& Society 28 (5): 653-74.

Jackson, Sue, and Tiina Vares. 2011. "Media 'Sluts': 'Tween' Girls' Negotiations of Postfeminist Sexual Subjectivities in Popular Culture." In New Femininities: Postfeminism, Neoliberalism and Subjectivity, edited by Rosalind Gill and Christina Scharff, 134-46. London: Palgrave Macmillan UK.

Jackson, Vicky, and Bregt Lameris. 2014. "Phantom Colours - Colour, Fashion and Cinema in the 1920s." Catwalk: The Journal of Fashion, Beauty and Style 3 (2): 19-46.

Jeffreys, Sheila. 2005. Beauty and Misogyny: Harmful Cultural Practices in the West. Routledge.

Jones, Geoffrey. 2008. "Blonde and Blue-Eyed? Globalizing Beauty, c.1945-c.19801." The Economic History Review 61 (1): 125-54.

Jones, Ms Charisse, and Kumea Shorter-Gooden. 2003. Shifting: The Double Lives of Black Women in America. HarperCollins.

Kandiyoti, Deniz. 1988. "Bargaining with Patriarchy." Gender \& Society 2 (3): 274-90.

Keith, Verna M., and Carla R. Monroe. 2016. "Histories of Colorism and Implications for Education." Theory Into Practice 55 (1): 4-10. 
Kiraly, Miranda, and Meagan Tyler. 2015. "Introduction." In Freedom Fallacy: The Limits of Liberal Feminism, edited by Miranda Kiraly and Meagan Tyler, x-xvii. Connor Court Publishing.

Lazar, Michelle M. 2011. "The Right to Be Beautiful: Postfeminist Identity and Consumer Beauty Advertising." In New Femininities: Postfeminism, Neoliberalism and Subjectivity, edited by Rosalind Gill and Christina Scharff, 37-51. London: Palgrave Macmillan UK. https://doi.org/10.1057/9780230294523_3.

Lebsack, Lexy. 2019. "Lipstick, Hair Dye, \& Power - How Beauty Is Fuelling A Revolution In North Korea." Refinery29. May 19, 2019. https://www.refinery29.com/en-gb/2019/05/233158/northkorea-beauty-products-makeup-smugglers.

Lehrman, Karen. 1997. The Lipstick Proviso: Women, Sex \& Power in the Real World. Doubleday.

McRobbie, Angela. 2007. "Top Girls?" Cultural Studies 21 (4-5): 718-37. https://doi.org/10.1080/09502380701279044.

McRobbie, Angela. 2009. The Aftermath of Feminism: Gender, Culture and Social Change. SAGE.

McRobbie, Angela. 2015. "Notes on the Perfect." Australian Feminist Studies 30 (83): 3-20. https://doi.org/10.1080/08164649.2015.1011485.

Mented Cosmetics. 2017. "Mented Cosmetics - Our Story." Mented Cosmetics YouTube Channel. January 14, 2017. Retrieved from https://youtu.be/MxFUiCIN94Y.

Merskin, Debra. 2007. "Truly Toffee and Raisin Hell: A Textual Analysis of Lipstick Names." Sex Roles 56 (9): 591-600. https://doi.org/10.1007/s11199-007-9201-9.

Mintel. 2019. "Color Cosmetics - US - July 2019." Retrieved from Mintel Academic Database:

https://academic.mintel.com/display/919754/.

Mintel. 2018. "Black Beauty Consumer - US - March 2018 - Market Research Report." Retrieved from Mintel Academic Database: https://academic.mintel.com/display/860343/.

Miranda, Leticia. 2017. "Why Rihanna's Red Lipstick Line Is So Groundbreaking." BuzzFeed News. December 22, 2017. https://www.buzzfeednews.com/article/leticiamiranda/heres-why-rihannais-the-perfect-person-to-sell-you-red.

Moran, Dominique, Judith Pallot, and Laura Piacentini. 2009. "Lipstick, Lace, and Longing:

Constructions of Femininity inside a Russian Prison." Environment and Planning D: Society and Space 27 (4): 700-720.

Murphy, Megan. 2015. "'I Do What I Want, Fuck Yeah!': Moving beyond 'a Woman's Choice.'" In Freedom Fallacy: The Limits of Liberal Feminism, edited by Miranda Kiraly and Meagan Tyler, 17-24. Connor Court Publishing.

Murrow, Lauren. 2012. "Iris Apfel for MAC Lipstick." The Cut. January 6, 2012. https://www.thecut.com/2012/01/iris-apfel-for-mac-lipstick.html. 
Ndichu, Edna G., and Shikha Upadhyaya. 2019. " "Going natural": Black women's identity project shifts in hair care practices." Consumption Markets \& Culture 22 (1): 44-67.

Negra, Diane, and Yvonne Tasker. 2007. Interrogating Postfeminism: Gender and the Politics of Popular Culture. Duke University Press.

Nittle, Nadra. 2018. "Before Fenty: Over 100 Years of Black Makeup Brands." Racked. January 23, 2018. https://www.racked.com/2018/1/23/16901594/black-makeup-brands-history.

Oppliger, Patrice A. 2008. Girls Gone Skank: The Sexualization of Girls in American Culture. McFarland.

Pallingston, Jessica. 1999. Lipstick: A Celebration of the World's Favorite Cosmetic. St. Martin's Press.

Parmentier, Marie-Agnès. 2016. "High Heels." Consumption Markets \& Culture 19 (6): 511-19.

Peiss, Kathy. 1990. "Making Faces: The Cosmetics Industry and the Cultural Construction of Gender, 1890-1930." Genders 7: 143-69.

Peiss, Kathy. 1998. Hope in a Jar: The Making of America's Beauty Culture. Metropolitan Books.

Pointer, Sally. 2005. The Artifice of Beauty: A History and Practical Guide to Perfumes and Cosmetics. Sutton.

P\&S Market Research. 2019. "Lipstick Market Is Expected to Reach \$13.4 Billion by 2024: P\&S Intelligence." GlobeNewswire News Room. March 27, 2019. http://www.globenewswire.com/news-release/2019/03/27/1773625/0/en/Lipstick-Market-isExpected-to-Reach-13-4-Billion-by-2024-P-S-Intelligence.html.

Redmond, Sean. 2003. "Thin White Women in Advertising: Deathly Corporeality." Journal of Consumer Culture 3 (2): 170-90.

Rogers, Steven, and Alterrell Mills. 2017. "Amanda and Kristen: Mented Cosmetics." Harvard Business School Case, December 2017: 318-093.

Safronova, Valeriya. 2017. "Maye Musk, 69, Is Now a CoverGirl." The New York Times, September 27, 2017, sec. Fashion. https://www.nytimes.com/2017/09/27/fashion/covergirl-maye-musk-elonmusk.html.

Scaraboto, Daiane, and Eileen Fischer. 2013. "Frustrated Fatshionistas: An Institutional Theory Perspective on Consumer Quests for Greater Choice in Mainstream Markets." Journal of Consumer Research 39 (6): 1234-57.

Schaffer, Sarah E. 2007. "Reading Our Lips: The History of Lipstick Regulation in Western Seats of Power." Food and Drug Law Journal, no. 1: 165-226.

Schuster, Julia. 2017. "Why the Personal Remained Political: Comparing Second and Third Wave Perspectives on Everyday Feminism." Social Movement Studies 16 (6): 647-59.

Scott, Linda M. 2005. Fresh Lipstick: Redressing Fashion and Feminism. Palgrave Macmillan. 
Siegel, Dina, and Yucel Yesilgoz. 2003. "Natashas and Turkish Men: New Trends in Women Trafficking and Prostitution." In Global Organized Crime: Trends and Developments, edited by Dina Siegel, Henk van de Bunt, and Damián Zaitch, 73-83. Studies of Organized Crime. Dordrecht: Springer Netherlands. $h$

Smith, Dorothy E. 1990. Texts, Facts, and Femininity: Exploring the Relations of Ruling. Routledge.

Stuart, Avelie, and Ngaire Donaghue. 2012. "Choosing to Conform: The Discursive Complexities of Choice in Relation to Feminine Beauty Practices." Feminism \& Psychology 22 (1): 98-121.

Tate, Shirley Anne. 2017. The Governmentality of Black Beauty Shame: Discourse, Iconicity and Resistance. Springer.

Thwaites, Rachel. 2017. "Making a Choice or Taking a Stand? Choice Feminism, Political Engagement and the Contemporary Feminist Movement." Feminist Theory 18 (1): 55-68.

Tungate, Mark. 2011. Branded Beauty: How Marketing Changed the Way We Look. Kogan Page Publishers.

Walker, Susannah. 2007. Style and Status: Selling Beauty to African American Women, 1920-1975. University Press of Kentucky.

Walter, Natasha. 1999. The New Feminism. Virago.

Warhurst, Chris, and Dennis Nickson. 2009. "'Who's Got the Look?' Emotional, Aesthetic and Sexualized Labour in Interactive Services." Gender, Work \& Organization 16 (3): 385-404.

Williamson, Judith. 1986. "Woman Is an Island: Femininity and Colonization." In Studies in Entertainment: Critical Approaches to Mass Culture, edited by Tania Modleski, 99-118. Indiana University Press.

Witz, Anne, Chris Warhurst, and Dennis Nickson. 2003. "The Labour of Aesthetics and the Aesthetics of Organization." Organization 10 (1): 33-54.

Wolf, Naomi. 1990. The Beauty Myth. Chatto \& Windus.

Yesil, Bilge. 2004. "'Who Said This Is a Man's War?': Propaganda, Advertising Discourse and the Representation of War Worker Women during the Second World War." Media History 10 (2): 103-17.

Young, Lola. 1999. "Racializing Femininity." In Women's Bodies: Cultural Representations and Identity, edited by Jane Arthurs and Jean Grimshaw, 67-89. A\&C Black.

Zanette, Maria Carolina, and Daiane Scaraboto. 2019. "From the Corset to Spanx: Shapewear as a Marketplace Icon." Consumption Markets \& Culture 22 (2): 183-99. 